\title{
The Effectiveness of Training of Philosophy with Children on Children's Attitudes Toward Human Values
}

\author{
Gülsüm Mehdiyev*, Kevser Tozduman Yaralı**
}

Makale Geliş Tarihi: 02/02/2020

Makale Kabul Tarihi: 01/05/2020

DOI: $10.35675 /$ befdergi.683349

\begin{abstract}
The purpose of this study is to investigate the effect of training of philosophy with children on attitudes of seventh graders towards human values. In the study, mixed model was used. In the quantitative dimension of the study, experimental design was made and the "Human Values Scale" was used as data collection tool. In the collection of data in qualitative dimension, document review and focus group interviews were used. The sample group of the study consisted of 20 children. A 10-week philosophy education program was applied to the children in the experimental group. Mann Whitney U test and Wilcoxon test were applied in the analysis of quantitative data. While descriptive analysis was applied for document analysis, content analysis was applied for focus group interview in analysis of qualitative data. As a result of the study, the philosophy education was found to positively affect the children's attitudes towards human values.
\end{abstract}

Keywords: Philosophy for children, philosophy with children, thinking education, values education

\section{Çocuklarla Felsefe Programınụn Çocukların İnsani Değerlere Yönelik Tutumları Üzerindeki Etkililiği}

$\ddot{O} z$

Bu araştırmanın amacl; çocuklarla felsefe programının yedinci sınıfa devam eden çocukların insani değerlere yönelik tutumlart üzerindeki etkisini incelemektir. Araştırmada karma model kullanılmıştır. Araştırmanın nicel boyutunda deneysel desen oluşturulmuş ve veri toplama aracı olarak "İnsani Değerler Ölçeği” kullanilmıştır. Nitel boyuttaki verilerin toplanmasında doküman incelemesi ve odak grup görüşmesinden yararlanılmıştır. Araştırmanın çalışma grubu 20 çocuktan oluşmuştur. Deney grubundaki çocuklarla 10 hafta süren felsefe eğitim programı uygulanmıştır. Nicel verilerin analizinde, Mann Whitney U testi ve Wilcoxon testi uygulanmıştır. Nitel verilerin analizinde doküman incelemesi için betimsel analiz, odak grup görüşmesi için içerik analizi yapılmıştır. Çalışmanın sonucunda felsefe eğitiminin çocukların insani değerlere yönelik tutumlarını olumlu etkilediği bulunmuştur.

Anahtar Kelimeler: Çocuklar için felsefe, çocuklarla felsefe, düşünme eğitimi, değerler eğitimi.

\footnotetext{
* Kırklareli Üniversitesi, Sağlık Yüksekokulu, Çocuk Gelişimi Bölümü, Kırklareli, Türkiye, e-mail: gulsmehdi@hotmail.com, ORCID:0000-0002-7654-7577

${ }^{* *}$ Kırklareli Üniversitesi, Sağlık Yüksekokulu, Çocuk Gelişimi Bölümü, Kırklareli, Türkiye, e-mail: kevseryarali@klu.edu.tr, ORCID: 0000-0002-7765-0461
}

Kaynak Gösterme: Mehdiyev, G. \& Tozduman Yaralı, K. (2020). The effectiveness of training of philosophy with children on children's attitudes oward human values. Bayburt Eğitim Fakültesi Dergisi [Journal of Bayburt Education Faculty], 15(29), 251-279. https://doi.org/10.35675/befdergi.683349 


\section{Introduction}

The presence of a close relationship between values and behaviors is undeniable. The existence of a thought at the basis of each action constitutes the main argument of this assertion. On the other hand, although the relationship between the values and behaviors has not been sufficiently clarified by social scientists (Boyatzis, Murphy \& Wheeler, 2000, p. 47-64), it seems more important to examine the thought systems and methods underlying values before actions. The relationship between thoughts and values has attracted the attention of many philosophers since ancient times (Charleton, 2008, p. 195). Famous philosophers produced basic texts on the subject in all ages especially Aristoteles, İbn Miskeveyh, Aquinas, Descartes, Kant, Nietzsche and Wittgenstein. However, unlike philosophers, today's social science considers revealing that the views are applicable as a prerequisite. In other words, measuring the effect of thoughts on values is an indispensable necessity. As in all other cognitive abilities and judgments, it is not difficult to predict that the formation of a particular value in a person occurs in pre-adulthood period. When the possibility of addressing the issue of cognitive abilities and judgments in a certain discipline is deprived, it is introspective attitude of the first thought coming to mind or more clearly judgement of the thought on thought. This field called as philosophy in technical sense has an independent identity mentioning human values such as justice, accuracy, awareness, love, and respect as well as thinking over thought. Since the formation of values occurs in pre-adulthood period, it can be asserted that one of the most important responsibilities of philosophy is the thinking education.

When it comes to thinking education, Jean Piaget is undoubtedly the first name that comes to mind. Piaget claims in his famous theory of cognitive development that especially children up to the age of 12 have no philosophical thinking skills (Piaget, 1933). The idea that children are deprived of philosophical thinking skills has been the subject of serious debates in the post-Piaget period and has been criticized by many researchers, especially Metthews (2000), Moshman (1998) and Pritchard (2002). Especially, Lipman has claimed that the thinking and logic education prior to the age of 12 stated by Piaget has a vital function (Lipman, 1988). The purpose of this study is to clarify this conceptual contrast rather than discussing whether or not children have no philosophical thinking skills and then to reveal the concrete impact of thinking education in accordance with the approach we adapt on the formation and development of human values. ${ }^{2}$ It is certainly not possible to grasp philosophy in preadolescence period in the sense that Piaget meant. For example, if it is considered that Kant wrote the first of his famous critics when he was 57 (1781) and the last one at the age of 69 (1790) and many research centers have been established to understand and interpret these texts over a period of more than two centuries, it would not be right to expect the individuals to have such an understanding in the early periods of cognitive development. On the other hand, it would not be right to ignore the right to use cognitive abilities that the individual had from the birth in understanding and

\footnotetext{
${ }^{2}$ See for a detailed discussion related to mentioned contradiction and especially advocate of former: Kitchener (1990).
} 
making sense of his/her environment as Kant argues. Therefore, when the thinking education is defined not as the familiarity to concepts and doctrines of philosophers without reaching a certain level of philosophical understanding but as the rational approach of persons towards the cases and events happening around them, both the above contradiction is eliminated and the goal of thinking education which is one of the most important obligations of philosophy is realized. There are different methods used in philosophy with children towards this objective; Lipman's Philosophy for Children (P4C), McCall's Philosophy Questioning Society and Nelson's Socratic Method are some of them. In this context, Mathew Lipman (1976) was the first person who stated that it is possible to do philosophy with children and to conduct thinking education in this way. Lipman claims that children can think abstractly and understand philosophical questions as from early ages. His aim is not to teach a particular philosophical view but to try to activate the child's own reasoning ability starting from universal concepts such as right, justice, and violence and to ensure the child to ask questions (UNESCO, 2007, p. 3). According to Lipman, students are accustomed to learn each other's thoughts and reasons, to listen attentively, and to form opposing ideas through philosophy education. Lipman (1976) and Matthews (2000) first accepted the developmental differences in children's cognitive capacities and stated that these differences could be eliminated with adequate experience and education, and this is possible with an appropriate training program (Kitchener, 1990, p. 429). According to Lipman (1976), the child has a doubt about the cognitive capacities of both himself and his classmates. Since he did not have a pre-acceptance that information can be obtained through mutual discussion and experience, he is insecure about the educational institution. In fact, the abstaining attitude of the child is the opposite of the imposing attitude of the educational institution. Children can show mysterious wisdom and infallible insight. Children whose opinions are confirmed by others behave even more clever (Lipman, 1976, p. 23). Haas (1976) says that even without adults, children are already amateur philosophers. Like philosophers, children ask a lot of questions, persistently seek answers to their questions and are not easily convinced. What distinguishes a dialogue with five-year-olds from adult dialogue is not the subtlety of philosophical reasoning in adults, but rather the lack of vocabulary in children (Droit, 2017). This phenomenon - the gap between children's vocabulary and philosophical thinking - leads to the idea that thinking appears first. It is clear that children have thoughts and arguments and children then try to put them into words (McCall, 2017, p. 31).

When the related literature is examined, it is seen that the philosophy studies conducted with children in order to ensure them to think healthy and to express their thoughts correctly are used with various names such as philosophy with children, thinking education, philosophy for children (Çotuksöken, 2015, p. 38). Although there is no consensus about the name, the method used to make philosophy with children is called as the "Socrates Method". This is a discussion, research and teaching method used by Socrates (Portelli, 1990, p. 142). According to Socrates, a midwife is needed for ideas to come into the world and he also sees himself as a midwife (Zeldin, 2014, p. 43). According to Leonard Nelson, a German philosopher, the Socrates Method is 
not the art of learning philosophy but the art of making philosophy; it is not the art of teaching knowledge about philosophers, but the art of making students philosophers (McCall, 2017, p. 94). Bynum (1976) stated that philosophy for children should be referred as a learning method rather than teaching method. Learning takes place through "discover method" in which they can show and share their thoughts through games, discussion, and other activities (Bynum, 1976, p. 3). Lone (2017) emphasizes that helping children to think philosophically improves their philosophical self. Childhood feelings which are lost when grown up can be remembered by listening to children and thus adulthood thoughts can be developed (Droit, 2017; Lone, 2017, p. 26).

The thinking education, which is an initiative supported also by UNESCO, is a serious need for children; because children have difficulty in expressing themselves as well as their feelings, thoughts and perceptions. This education given at an early age is also important for the children in terms of establishing the logic relationship, recognizing their emotions, expressing themselves, being aware of different opinions and revealing these self-confident individuals without the fear of saying anything wrong (UNESCO, 2005). Making philosophy with children allows children to gain the ability to handle the truth along with protecting their natural desires for finding the truth even if it does not give pleasure. It develops skills and tools to judge themselves. Children, who are not left to stay on their own, grow up as active citizens without being left vulnerable in the ruthless world (McCall, 2017, p. 189). According to the common opinion in the related literature, philosophy/thinking education with children provides significant gains in many areas such as critical thinking, reasoning, reading, mathematics, concentration, collaboration, self-esteem, self-confidence, reducing bullying, communication and interpersonal relationships (Akkocaoğlu Çayır \& Akkoyunlu, 2016; Burroughs \& Tuncdemir, 2017; Cam, 2014; Garrat \& Piper, 2011; McCall, 2017; Splitter, 2011).

Philosophers have explored the origin of human values from the ancient Greek to the present time. Aristoteles describes how virtuous behavior can help one to be good for her/himself and others. When the virtues adopted by Aristoteles are examined, it is seen that they are described as a tendency to think, desire, feel and act integrated with each other (Horner \& Westacott, 2011, p. 175). The main focus of ethics is how people should live their lives. Ethics explores the rationality of acquiring value judgments about the management of our lives (Wartenberg, 2018, p. 81). Moral philosophy education is necessary for individuals to reflect the values in their lives and society (Charleton, 2008, p. 201). While security issues exist even in the most livable places in the world, human values have been a highly debatable issue. There are various views on what human values are. For example, according to Seligman (2007), values are considered as virtuous behaviors. Seligman grouped the virtuous behaviors as character forces; wisdom, knowledge, humanity, love, justice, moderation, courage and transcendence. Kinnier, Kernes and Dautheribes (2000) formed four main categories for universal moral values and stated these categories as commitment to a transcendent entity, self-esteem along with humility, self-discipline, accepting personal responsibilities, respect and care for others, and care for other 
creatures and the environment. Kulaksizoğlu (2014), on the other hand, classified moral (human) values as liking, behaving correctly, doing good, being peaceful, working, getting information (Kulaksızoglu, 2014, p. 159). In the $18^{\text {th }}$ National Education Council Workshop Report, Ministry of National Education (2010) determined many values that need to be gained by the students such as love, responsibility, respect, tolerance, fairness, empathy, independent and free thinking (Ministry of National Education, 2010). Although the treatment or classification of values varies, how/in which way they will be brought to children is considered important.

Even with the repetition, it is necessary to repeat that the measurement of the effect of thought on values in terms of the logic of today's social sciences is inevitable. Primary aim of this study which was conducted using embedded design in the mixed model is to examine the effectiveness of the philosophy education with children on attitudes of seventh grade students toward human values. In the study, the qualitative data were embedded within the main design of experimental study. The quantitative data were used for testing the theory which estimates that the philosophy education program, which was the independent variable, would have an effect on children's attitudes toward human values, which was the dependent variable. The experimental design to be used in the quantitative model was integrated with the data to be acquired from the qualitative model in the study for the purpose of revealing the effect of the philosophy education with children on children's attitudes toward human values. While the quantitative data revealed whether or not children's attitudes toward human values were affected by the philosophy education program, the qualitative data discovered how children were affected by the philosophy education program.

\section{Method}

\section{Research Model}

In the study, mixed model and embedded design were used. The main purpose of the embedded design is to use different data types together to improve the application of qualitative and quantitative designs (Creswell \& Plano Clark, 2015). The reason behind why mixed model was used in this study was to support the data, to be collected using quantitative method, with qualitative data and to reveal to what extent and how training of philosophy with children affect them. Figure 1 shows the flow chart of the embedded design used in this study. 


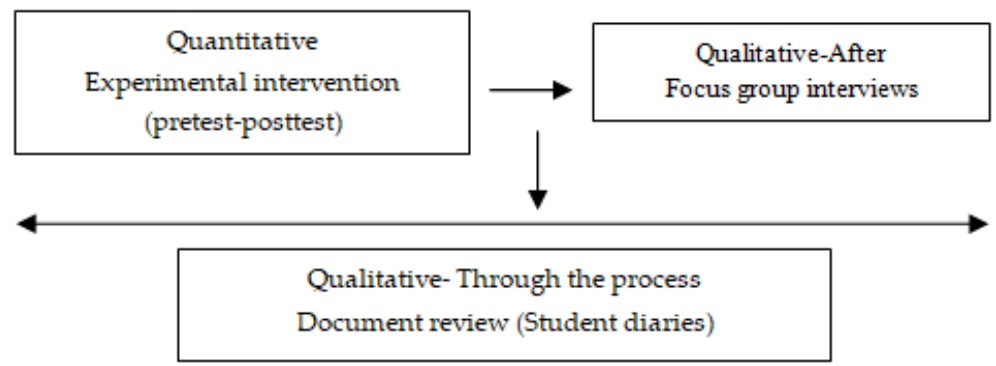

Figure 1. Flow chart

Experimental design with pretest-posttest control group was used in the quantitative dimension of the study (Büyüköztürk, Kılıç Çakmak, Akgün, Karadeniz \& Demirel, 2018). While the Human Values Scale was used in the collection of quantitative data, document review and focus group interviews were utilized to collect qualitative data. Student diaries were formed at the end of each session as from the first week of the training of philosophy with children. Student diaries, which are evaluated as "documents produced by the researcher" were prepared to obtain more information about the event/person/situation in this study (Merriam, 2015). The students wrote their opinions about their experiences and thoughts after each session. In the last week of the philosophy program, a focus group interview was held with all students who participated in the philosophy program.

\section{Sample Group}

A total of 20 students aged 13 years including 10 students in the experimental group and 10 in control group continuing a secondary school in the city center of Kirklareli participated in the study. The students were determined according to purposeful sampling method. Accordingly, 10 seventh graders, who can participate in the philosophy education program on Saturdays and were voluntary to participate were selected for the experimental group. Since all children who were voluntary and stated that they could participate on Saturdays were girls, 10 children determined for the control group were female. The training of philosophy with children was applied to the children in the experimental group once a week for 10 weeks and any intervention other than current curriculum was not performed to children in the control group.

\section{Data Collection Tools}

In the study, "Human Values Scale", developed by Dilmac (2007), was used before and after the philosophy program (as pretest and posttest). On the last day of the training of philosophy with children, "focus group interview" was held with the children who received the application. In addition, at the end of each session, student diaries in which the children wrote their opinions and views about the activity process of that day were used. 


\section{Human values scale}

Human Values Scale (HVS), developed by Dilmaç (2007), is a five-point Likert type. It is composed of six subscales including responsibility, friendship/companionship, being peaceful, respect, tolerance and honesty and a total of 42 items. As a result of the validity and reliability studies of the scale developed for secondary school students conducted with 322 students, it was found that the internal consistency coefficient alpha was 92 and the stability coefficient was found as .87 as a result of test-retest. Then, in the study conducted by Tahiroğlu, Kayabaşı and Kayabaş1 (2013), reliability of HVS for $8^{\text {th }}$ grade students was tested. The reliability coefficient (Cronbach's Alpha) of the scale applied to 169 students was found to be .77 .

\section{Focus group interview}

On the last day of the training of philosophy with children, a focus group interview was held with all the children ( 10 children) who participated in the education program. The interview was conducted in an environment used as a music workshop in a circle seating arrangement. The focus group interview lasted for fifty-five minutes. During this time, questions and answers of the children were recorded on two voice recorders. Five open-ended questions were asked to children during the interview. In the focus group interview, the children were asked the following questions: "What influenced you most during the Philosophy activity? How did you apply what you had learned here in your daily life/classroom? If you want to tell a friend what we talked about here, what would you tell her/him about this activity?" How do you think the presencel necessity of such a course would affect social life? What would you like to change about the content and implementation of philosophy activities? What would be your suggestions?"

\section{Student diaries}

During the 10-week program, student diaries in which the children shared their opinions and suggestions on the topic discussed were prepared at the end of each session. For this purpose, notebooks were given to each child during the first session, the children wrote their previous thoughts about the subject and their opinions after the session (remained the same or changed) at the end of each session.

\section{Data Collection}

The data were collected between 19.04.2019 and 10.06.2019 in the spring semester of 2018-2019 academic year. The training of philosophy with children started at 10:30 and was completed at 12.00 at the latest every Saturday. Pretest was applied on 19.04.2019 and posttest was applied on 10.06.2019 for the children in the experimental and control groups. The focus group interview was conducted on 08.06.2019. The training of philosophy with children was conducted in an environment used as a music workshop independently of the classroom. While 
cushions were used in some sessions, chairs were used in some sessions according to children's preference.

\section{The Training of Philosophy with Children}

A 10-week training program was developed by the researchers. Before developing the program, the researchers reviewed the literature on philosophy with children (Droit, 2017; McCall, 2017; Worley, 2019). The content of the program was prepared based on Lipman's approach of "philosophy for Children (P4C)". The topics determined in the program was formed by considering the values specified in the Values Education Directive of the Ministry of National Education. Stimulating texts to be used in the program were selected and the questions to be used at sessions were prepared based on these texts. The subjects to be covered within the scope of the event were respectively What is philosophy?, The subjects of Opinion/Believing and Knowing, Good and Bad, Truth and Fake, Moral and Non-Moral, Happiness and Unhappiness, Beauty and Ugliness, Nature and Pollution, War and Peace/Violence and Nonviolence, Free and Non-free/Justice and Injustice/Rights and Assignments (Table 1). Each week, the stimulating texts that could be used for each topic were determined, the questions that can direct the discussion based on stimulating texts were prepared and the aimed gains were determined after each session. The prepared program was submitted to two experts from philosophy and child development fields in order to take their opinions. Although the duration of each session varied depending on the subject, it lasted for averagely 60-70 minutes. Philosophy is described as "thinking about a certain subject in a certain style". Reasoning process was utilized for values subject during the application in this study. The role of the researcher during the application was "a curious facilitator" during the management of the philosophy sessions (Worley, 2019). Conversations were recorded during the interview and dictated after the session. For example, "Alim" which is a joke of Nasrettin Hodja was shared with the children during the week when the subject of "believing and knowing" is dealt with. A part of the dialogue made in the period after sharing the joke with the children was as follows:

Ayça: I read somewhere that sometimes knowledge can make people do something wrong. For example, a person drives fast and crashes thinking that he/she can drive very well.

Ela: What I hate the most is that a person who does not know a matter talks as if he/she knows it and the one who knows does not speak.

Süreya: For example, a doctor may be very good in medicine, but when a lawyer speaks in his field, the doctor should listen to him.

Ela: Brain and belief seem the opposite for me, I think we believe more with our emotions.

Ada: Believing is about the heart, knowledge is about the brain; I also think that they are opposite.

Ecrin: Believing is to hope that the thoughts of others are so while the knowledge is proving.

Esra: We prefer to believe rather than knowing 
Saliha: knowledge can be proven but belief is a concept that cannot be proven. Ela: I will ask something: "If we can prove our belief, will that be knowledge?' Ada: Well, can knowledge confute belief?

Ela: I believe it can.

Saliha: I think it cannot. If someone wants to believe, he/she continues to believe that. Nil: I think it cannot confute, if it does, there must be a deficit with the belief. If the belief can be confuted, that means we did not believe.

Ayça: For example, if we think of it as science, if they are in the same opinion but defending different things, how do we know which is the exact knowledge?

A dialogue in the week when on the subject "Good and Bad" was discussed was as follows:

Researcher: - What it takes to say something good?

Ela: It should exhibit the things I think is right.

Ecrin: I'd say it's good if it is helpful for me.

Zehra: To understand that something is good, you need to see the bad.

Ela: For example, in Turkish TV series, you identify yourself with the evil character in order to respond to the good girl roles. Because those in good roles do everything. Süreya: People may have reasons to be evil.

Ada: It is a good thing as long as it does not do anything to annoy me.

Saliha: What's good for me can be bad for someone else. Robin Hood is good for the poor and bad for the rich since he takes from rich people and gives to the poor.

Table 1 shows the process of the philosophy program with children 
Table 1.

The Process of the Philosophy with Children Program

\begin{tabular}{|c|c|c|c|c|}
\hline Week & Content & Text (Story, Joke etc.) & Related Questions & Gains \\
\hline 1. & $\begin{array}{l}\text { What is } \\
\text { Philosoph? }\end{array}$ & $\begin{array}{l}\text { Talking philosophy with } \\
\text { your kids (Droit, 2017) }\end{array}$ & $\begin{array}{l}\text {-What is philosophy? } \\
\text {-Are the things done by philosophers considered as work? } \\
\text {-Who can make philosophy? } \\
\text {-Is it necessary to know philosophy? }\end{array}$ & $\begin{array}{l}\text {-Telling whether or not he/she agrees with an opinion with its } \\
\text { reasons. } \\
\text {-Recognizing the characteristics of philosophy questions. } \\
\text {-Noticing the similarities and differences between philosophy and } \\
\text { science. }\end{array}$ \\
\hline 2. & $\begin{array}{l}\text { Believing/O } \\
\text { pinion and } \\
\text { Knowing }\end{array}$ & $\begin{array}{l}\text { The Bear and The Fox } \\
\text { (Aesop's Fables, 2003) } \\
\text { Scientist (Brenifier and } \\
\text { Millon, 2011) }\end{array}$ & $\begin{array}{l}\text {-What does it take to content something? } \\
\text {-Why do people want to know? } \\
\text {-Why is it sometimes difficult to say "I do not know"? } \\
\text {-Why do people feel jealous? }\end{array}$ & $\begin{array}{l}\text {-Comprehending the difference between knowing and believing. } \\
\text {-Realizing that knowledge is justified belief. } \\
\text {-Analyzing the accuracy of knowledge. } \\
\text {-Presenting what he/she knows with convincing reasons. }\end{array}$ \\
\hline 3. & $\begin{array}{l}\text { Good and } \\
\text { bad }\end{array}$ & $\begin{array}{l}\text { The Perfect Horse Tale } \\
\text { (Direk, 2011) }\end{array}$ & $\begin{array}{l}\text { How do you decide if something is good or bad? } \\
\text { How is the relationship between the goodness and } \\
\text { perfection? } \\
\text { Why is self more important than appearance? }\end{array}$ & $\begin{array}{l}\text {-Comprehending the difference between good and evil. } \\
\text {-Realizing the difference between what is really good and what } \\
\text { looks good. } \\
\text {-Realizing that goodness is a virtue. }\end{array}$ \\
\hline 4. & $\begin{array}{l}\text { Truth and } \\
\text { Fake }\end{array}$ & $\begin{array}{l}\text { Donkey (Brenifier and } \\
\text { Millon, 2011) } \\
\text { Emperor's New Clothes } \\
\text { (Direk, 2012) }\end{array}$ & $\begin{array}{l}\text {-What is real, what appears real? } \\
\text {-Why do we have good reasons to lie sometimes? } \\
\text {-Why do people lie? } \\
\text {-Do animals always tell the truth? }\end{array}$ & $\begin{array}{l}\text {-Realizing that our senses can mislead us. } \\
\text {-Evaluating the relationship between lies and truth in moral } \\
\text { perspective. } \\
\text { - Empathizing about the effect of truth and lie. }\end{array}$ \\
\hline 5. & $\begin{array}{l}\text { Beauty and } \\
\text { ugliness }\end{array}$ & $\begin{array}{l}\text { Clothes make the man } \\
\text { (Brenifier and Millon, 2011) } \\
\text { The ugly duckling (Direk, } \\
\text { 2012) }\end{array}$ & $\begin{array}{l}\text {-Does the appearance of people show who they are? } \\
\text {-What is the difference between appearance and reality? } \\
\text {-Can we be sure if this duck is ugly? } \\
\text {-Can we set a standard beauty criterion? }\end{array}$ & $\begin{array}{l}\text {-Comprehending that appearance can be deceptive. } \\
\text {-Realizing that beauty is relative. } \\
\text { - Realizing the relationship between beauty and value/effect. } \\
\text { - Trying/laboring to make something good/for beauty. }\end{array}$ \\
\hline 6. & $\begin{array}{l}\text { Moral and } \\
\text { Non-Moral }\end{array}$ & $\begin{array}{l}\text { Piaget's Broken Cups Story } \\
\text { Give me my ten-day wage } \\
\text { (Fuat, 2015) }\end{array}$ & $\begin{array}{l}\text {-What makes a person guilty? } \\
\text { - How do we decide if something is moral? } \\
\text { - How is a moral person? }\end{array}$ & $\begin{array}{l}\text {-Establishing the relationship between morality and conscience. } \\
\text {-Realizing that it is necessary to be virtuous in order to be moral. } \\
\text {-Exhibiting virtuous behaviors to be moral. }\end{array}$ \\
\hline 7. & $\begin{array}{l}\text { Happiness } \\
\text { and } \\
\text { Unhappines } \\
\mathrm{s}\end{array}$ & $\begin{array}{l}\text { The key (Brenifier and } \\
\text { Millon, 2011) } \\
\text { When Moşe Left the City } \\
\text { (Liberman, 2015) }\end{array}$ & $\begin{array}{l}\text {-Is it the same thing that makes everyone happy? } \\
\text {-Is happiness a feeling or a situation? Why? } \\
\text {-Do we have to search to find something? } \\
\text {-What makes you the happiest? }\end{array}$ & $\begin{array}{l}\text {-Realizing what he/she has to do to be happy. } \\
\text {-Establishing the relationship between knowing yourself and } \\
\text { happiness. } \\
\text { - Asking "What makes me happy?" instead of asking "Am I } \\
\text { happy", } \\
\text {-Exhibiting virtuous behaviors to be happy. }\end{array}$ \\
\hline
\end{tabular}




\begin{tabular}{|c|c|c|c|c|}
\hline 8. & $\begin{array}{l}\text { Nature and } \\
\text { Pollution }\end{array}$ & $\begin{array}{l}\text { Starfish (Direk, 2012) } \\
\text { Yes, but that's another } \\
\text { pleasure. (Labbe and } \\
\text { Beurier, 2016) }\end{array}$ & $\begin{array}{l}\text {-Why is it important to do good things? } \\
\text {-Is nature responsible to us or are we responsible to } \\
\text { nature? Why? } \\
\text { - What would be a life/environment consisting only of } \\
\text { concrete without nature? How did it make us feel? }\end{array}$ & $\begin{array}{l}\text { - Comprehending the relationship between nature and human. } \\
\text { - Realizing the relationship between keeping the environment } \\
\text { clean and responsibility sense. } \\
\text {-Attempting to keep the environment clean. }\end{array}$ \\
\hline 9. & $\begin{array}{l}\text { Violence } \\
\text { and } \\
\text { nonviolence } \\
\text { War and } \\
\text { peace }\end{array}$ & $\begin{array}{l}\text { The Blanket's gone, the } \\
\text { fight is done (Fuat, 2015) } \\
\text { When there is a power } \\
\text { managing everything } \\
\text { (Labbe and Beurier, 2016) }\end{array}$ & $\begin{array}{l}\text {-How is the place of violence and war? How does it make } \\
\text { someone to feel? } \\
\text {-Why do people resort to violence? } \\
\text {-Which method can we use instead of violence? } \\
\text {-How is a peace person? What do they do? }\end{array}$ & $\begin{array}{l}\text { - Comprehending both individual and social effects of war and } \\
\text { violence. } \\
\text {-Realizing that violence harms perpetrator and victim. } \\
\text { - Solving his/her problems without using violence. }\end{array}$ \\
\hline 10. & $\begin{array}{l}\text { Free and } \\
\text { Non-Free } \\
\text { Justice and } \\
\text { Injustice } \\
\text { Rights and } \\
\text { Assignment } \\
\text { S }\end{array}$ & $\begin{array}{l}\text { Planet without assignment } \\
\text { (Labbe and Beurier, 2016) } \\
\text { Turban (Brenifier and } \\
\text { Millon, 2011) } \\
\text { Painter's Mirror (Liberman, } \\
\text { 2015) }\end{array}$ & $\begin{array}{l}\text {-Are we aware of our responsibilities? } \\
\text {-Should a rule apply to everyone? } \\
\text {-When do you feel you are subjected to injustice? } \\
\text {-How do you behave when you are subjected to injustice? }\end{array}$ & $\begin{array}{l}\text {-Comprehending that freedom has limits. } \\
\text { - Realizing that lawlessness is not freedom. } \\
\text {-Realizing that understanding the reasons of the rules is necessary. } \\
\text {-Associating the responsibility concept with daily life. } \\
\text {-Establishing a relationship between rules and responsibility. }\end{array}$ \\
\hline
\end{tabular}




\section{Data Analysis}

\section{Analysis of quantitative data}

A packaged software was used in the analysis of quantitative data. All 42 items of the Human Values Scale were analyzed in one dimension with the thought that children's attitudes towards human values should be addressed as a whole. Whether or not the score distribution met the normality and homogeneity assumptions was tested by calculating the pretest scores of the experimental and control groups before the experimental process and their posttest scores after the experimental process in order to decide parametric/nonparametric tests to be used in the study. For this purpose, the skewness and kurtosis values of the pretest and posttest total scores obtained for each group were examined in order to determine whether or not the normality assumption is met. If these coefficients were between -1 and +1 , the distribution of the scores was assumed to be normal. Levene's test was conducted to test homogeneity assumption. Homogeneity assumption of variances was accepted to be met when the significance scores are greater than 0.05 as a result of the test. In the normality condition, two-factor ANOVA method was used for mixed designs that can deal with within-group, between-group and common effect between the pretest and posttest in order to determine the effect of philosophy activity with children (Büyüköztürk, 2011). In cases where the assumptions were not met, it was examined whether or not posttest and pretest difference scores differed according to experimental and control groups. For this purpose, unrelated samples t-test was used in cases where the normality assumption was met and otherwise, Mann Whitney U test was used. In addition, in order to examine if the pretest and posttest scores of children in both experimental and control groups differed or not, related samples ttest was used in cases where the normality assumption was met and otherwise, Wilcoxon test was used.

\section{Analysis of qualitative data}

While content analysis was used for focus group interview in analysis of qualitative data, descriptive analysis was used for document analysis. For this purpose, the voice recording data of the focus group interview were categorized for the data dictated by the researcher. For the themes used in the analysis of the data related to the student diaries (Wisdom and knowledge, humanity, love, justice), the virtuous behavior titles found in Seligman (2007) were benefited.

\section{Validity and Reliability Studies}

One of the validity strategies used in analyzing the qualitative data of this study is transferability which is also called as external validity. Therefore, quotations expressing the children's views in both document review section and the focus group interview section were used in order to ensure the consistency of the results with the presented data. As another strategy, different data collection methods have been conducted to ensure internal validity, both document review and focus group 
interview were used in qualitative dimension (Merriam, 2015; Yıldırım \& Şimşek, 2013).

The reliability strategies used in the study were the expert review, consensus among experts and the use of voice recorder. In order to have consensus, the categories prepared by the first researcher were re-evaluated by the second researcher by considering data and consensus was reached in the conflicted categories. Reliability analysis was conducted by using inter-coder reliability formula of (Miles and Huberman, 2015): [Consensus/ (Consensus + Disagreement) X 100]. Reliability percentage was calculated as $91 \%$.

\section{Ethical Considerations}

Prior to the study, application permission was obtained from Kirklareli Provincial Directorate of National Education. The appropriate place and time were discussed with the principal of the school where the study would be conducted and the students were informed about the application. The volunteer consent forms were sent to the families of the students in the experimental group informing them about the place, time and process of the education and stating that they have the right to leave the application at any time they want. It was ensured that all children participating in the study were voluntary and nicknames were used for the names of the children.

\section{Results}

The results of the study were presented in two parts (qualitative and quantitative) since the study was conducted in a mixed model.

\section{Results on Quantitative Data}

Table 2 shows the descriptive statistics of the pretest and posttest scores of the children in the experimental and control groups from the Human Values Scale.

Table 2 .

Descriptive Statistics of Pretest and Posttest Scores of Human Values Scale

\begin{tabular}{ccccccccc}
\hline \multirow{2}{*}{ Test } & Group & $\mathrm{n}$ & $\bar{X}$ & $\begin{array}{c}\text { S. } \\
\text { Deviatio } \\
\mathrm{n}\end{array}$ & Min. & Max. & $\begin{array}{c}\text { Skew } \\
\text { K }\end{array}$ & Kurt. \\
\hline \multirow{2}{*}{ Pretest } & $\begin{array}{c}\text { Experim } \\
\text { ental }\end{array}$ & 10 & 161.20 & 17.05 & 137.00 & 188.00 & 0.28 & -1.10 \\
\cline { 2 - 9 } & Control & 10 & 169.10 & 11.58 & 153.00 & 189.00 & 0.04 & -0.52 \\
\hline \multirow{3}{*}{ Posttest } & $\begin{array}{c}\text { Experim } \\
\text { ental }\end{array}$ & 10 & 183.20 & 13.05 & 167.00 & 205.00 & 0.45 & -1.16 \\
\cline { 2 - 9 } & Control & 10 & 173.70 & 12.88 & 158.00 & 204.00 & 1.48 & 3.01 \\
\hline
\end{tabular}

When the pretest mean scores from Human Values Scale in Table 2 were examined, it was observed that the mean score of the experimental group was 161.20 and the mean score of the control group was 169.10 . When the kurtosis and skewness values were taken into consideration, it can be asserted that these values were between 
-1 and +1 in the control group but they were outside the range between -1 and +1 in the experimental group; in other words, the pretest scores showed normal distribution in the control group but they did not show normal distribution in the experimental group. When the posttest mean scores of the human values scale were considered, it was observed that the mean score of the experimental group was 183.20 and the mean score of the control group was 173.70. When the kurtosis and skewness values were taken into consideration, it can be asserted that these values were not between -1 and +1 , that is, the posttest scores did not show normal distribution in both experimental and control groups. When the results obtained from the descriptive analyses were examined, Mann Whitney U test was used to compare the pretest scores since pretest scores of the experimental and control groups did not show normal distribution in both groups. In order to test the effectiveness of the philosophy program with children, Mann Whitney U test and Wilcoxon test were applied for pretest and posttest score differences since pretest and posttest scores did not show normal distribution.

\section{Results for the period Before the Philosophy Program with Children}

Table 3 shows the results of the Mann Whitney $U$ test applied to investigate if the pretest scores of the children in the experimental and control groups for the human values scale show difference.

Table 3.

Mann Whitney U Test Results for Investigating the Difference in Pretest Scores of Human Values Scale According to the Experimental and Control Groups

\begin{tabular}{cccccc}
\hline Group & $\mathrm{n}$ & Mean Rank & Total Rank & $\mathrm{U}$ & \\
\hline Experimental & 10 & 8.90 & 89.00 & \multirow{2}{*}{34.00} & \multirow{2}{*}{0.25} \\
\hline Control & 10 & 12.10 & 121.00 & & \\
\hline
\end{tabular}

When Mann Whitney U test results in Table 3 were examined, it was determined that the pretest scores of the Human Values Scale did not show a statistically significant difference according to the experimental and control groups $(\mathrm{p}>0.05)$. Therefore, it can be asserted that experimental and control groups had similar characteristics before the philosophy education.

\section{Results for the Effectiveness of the Philosophy Program with Children}

Table 4 shows Mann Whitney U test results where pretest-posttest difference scores related to human values scale were analyzed according to the experimental and control groups to investigate the effectiveness of the philosophy program with children.

Table 4.

Mann Whitney U Test Results for the Investigation of Human Right Scale PretestPosttest Difference Scores according to the Experimental and Control Groups.

\begin{tabular}{cccllll}
\hline & Group & $\mathrm{n}$ & Mean Rank & Total Rank & $\mathrm{U}$ & $\mathrm{p}$ \\
\hline $\begin{array}{c}\text { Human Values } \\
\text { Difference } \\
\text { (Posttest - Pretest) }\end{array}$ & Experimental & 10 & 15.40 & 154.00 & & \\
\cline { 2 - 5 } & Control & 10 & 5.60 & 56.00 & $0.00^{*}$ \\
\hline
\end{tabular}


As seen in Table 4, pretest-posttest score differences of the human values scale showed a statistically significant difference according to the experimental and control groups $(\mathrm{U}=1.00, \mathrm{p}=0.00, \mathrm{p}<0.05)$. It can be asserted that the pretest-posttest difference scores differed in favor of the experimental group according to the experimental and control groups. In addition, Table 5 shows the results of Wilcoxon test conducted to investigate whether or not pretest and posttest scores of the children in both experimental and control groups showed any difference in order to examine the effectiveness of the philosophy program.

Table 5 .

Wilcoxon Test Results for The Difference In The Pretest-Posttest Difference Scores of The Experimental and Control Groups from The Human Values Scale.

\begin{tabular}{ccccccc}
\hline Wilcoxon & Posttest-Pretest & $\mathrm{n}$ & Mean Rank & Total Rank & $\mathrm{z}$ & $\mathrm{p}$ \\
\hline \multirow{3}{*}{ Experimental } & Negative rank & 0 & 0.00 & 0.00 & & \\
\cline { 2 - 5 } & Positive rank & 10 & 5.50 & 55.00 & \multirow{2}{*}{-2.81} & \multirow{2}{*}{$0.01^{*}$} \\
\cline { 2 - 5 } Control & Equal & 0 & & & & \\
\cline { 2 - 5 } & Negative rank & 1 & 9.00 & 9.00 & & \\
\cline { 2 - 5 } & Positive rank & 9 & 5.11 & 46.00 & \multirow{2}{*}{0.06} \\
\cline { 2 - 5 } & Equal & 0 & & & & \\
\hline
\end{tabular}

When results of the Wilcoxon test for the related samples in Table 5 were examined, the children in the experimental group showed a significant difference before and after the philosophy education program $\left(\mathrm{Z}_{\text {experimental }}(10)=-2.81, \mathrm{p}=0.01\right.$, $\mathrm{p}<0.05)$. After the training program of philosophy with children, the scores of the children in the experimental group from the human values scale increased. When the mean and total ranks were taken into consideration, it was observed that this difference was in favor of positive ranks, that is, posttest scores. The results of Wilcoxon test applied for control group were examined, scores of the children in the control group before and after the experimental process did not show any significant difference $\left(\mathrm{z}_{\text {control }}=-1.89, \mathrm{p}=0.06, \mathrm{p}>0.05\right)$.

When considering that the pretest scores of the human values scale did not show difference, posttest pretest score differences showed difference in favor of the experimental group, posttest pretest scores of the children in the experimental group differed in favor of the posttest scores and posttest pretest scores of the children in the control group did not differ, it can be said that the philosophy program led to a positive effect on the children's attitudes towards human values (Figure 2). 


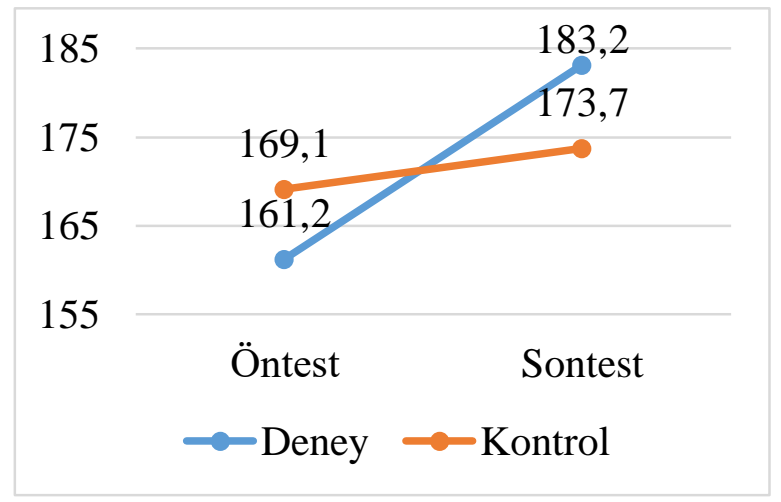

Figure 2. Graph showing the Effectiveness of the Philosophy Program with Children

\section{Results Related to Qualitative Data}

Table 6 shows the categories formed by analyzing the diaries of the children in the experimental group.

Table 6.

Themes and Categories Formed for Children's Diaries

\begin{tabular}{ll}
\hline Themes & Doubt / Curiosity \\
\hline \multirow{2}{*}{ Wisdom and Knowledge } & Perspective \\
& Thinking \\
\hline \multirow{3}{*}{ Humanity and Love } & Respect / Tolerance \\
& Relativity \\
\hline \multirow{2}{*}{ Justice } & Self-Control \\
\hline
\end{tabular}

\section{Wisdom and knowledge}

The first theme used in the content analysis of student diaries was the wisdom and knowledge theme (Image 1, Image 2). Under this theme, there categories were formed including doubt/curiosity, perspective and thinking. For example, the expressions "I had an interest and curiosity in philosophy before, now I have realized that my interest in philosophy has increased with this course. The fact that everyone put forward an idea and we interpreted that idea made me happy." (S1la); "...I learned that philosophy is to seek knowledge..." (Ecrin) can be given as examples for doubt/curiosity category. The expressions "... I have learned that philosophy is an art of thinking. We talked about the differences between knowledge and belief, and I have realized that it is different for everyone, that is really weird. Because, you think so but others think otherwise. I learned that there are different perspectives and they 
all come to a different conclusion." (Süreya); "Before I came here, I thought that philosophy made people aware but people who have weak belief to their religion should not be interested (since these two conflict with each other) but I have learned after this course that belief and knowledge should not be mixed." (Ada) can be given as examples for perspective category. The expression "I did not know anything about philosophy when I came here, but in this course, I have learned that what really matters is not a single answer is right in multiple choice questions as taught to us but how we got that response." (Zehra) can be given as an example for thinking category.

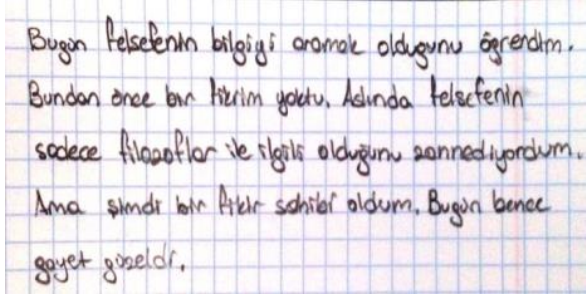

Image 1 (Senem)

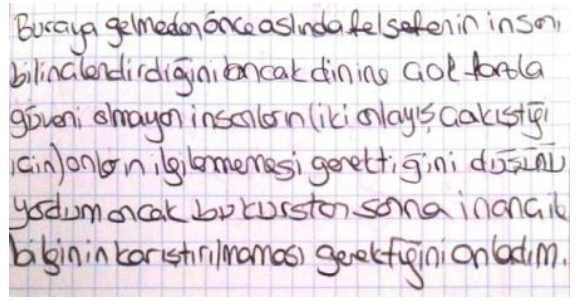

Image 2 (Nergis)

\section{Humanity and love}

The second theme used in the content analysis of student diaries was the theme of humanity and love (Image 3, Image 4, Image 5). Under this theme, three categories were created: respect / tolerance, relativity and self-control. For example, the expressions "I began to think that beauty is not the appearance but it is the behavior. I started to think that beauty is different for everyone and the reason behind why evil characters in the cartoons are ugly is an indicator of reflecting the ugliness inside to the outside (Saliha) can be given as an example for respect/tolerance category. The expressions "I knew that people's opinions might be different from some people, but beside this knowledge, I realized that the concepts of right and wrong and most of things are relative concepts and there are many things (book) that can be read about these subjects. " (Nil); “...In fact, we have learned that beauty is a concept that can vary from people to people and that beauty cannot be judged by appearance..." (Sila) can be given as examples for relativity category. The expressions "... Intention is the beginning of everything. The intention that separates what is right and what is not. Self-control is the thing everyone must have but some people do not have that " (Süreya) "... I started to think that dose of everything should be adjusted well and in fact unhappiness can bring happiness at any moment and we should seek happiness within us." (S1la); "People want to be seen when they do good things, those who want to do bad things want to disappear." (Ecrin) can be given as examples for self-control category. 


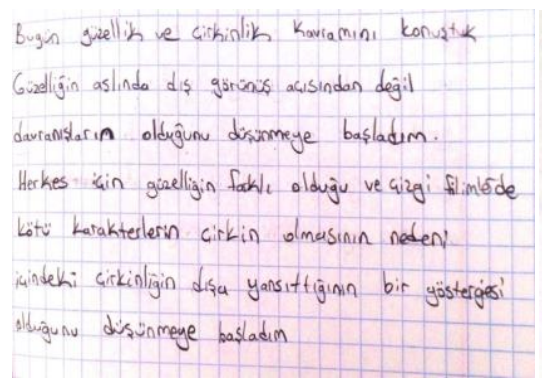

Image 3 (Saliha)

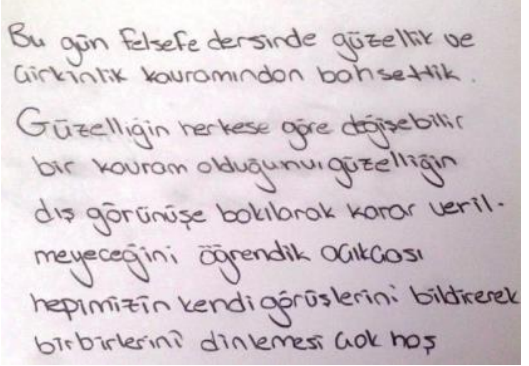

Image 4 (Sıla)

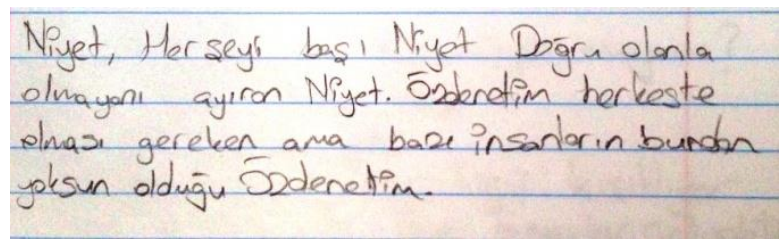

Image 5 (Süreya)

\section{Justice}

The third theme used in the content analysis of the students' diaries was the theme of Justice (Image 6, Image 7). Two categories were formed under this theme; freedom and responsibility. For example, the expression "We talked about freedom in this class. In fact, we have learned that our responsibilities constitute freedom. If everyone acted as they desire and do not fulfill their responsibilities, our freedom would have been restricted." (Zehra) can be given as an example for freedom category. The expression "Before I started this class, I thought that responsibilities limited our freedom, and now I think that responsibilities yield to freedom.." (Nil) can be given as an example for the responsibility category.

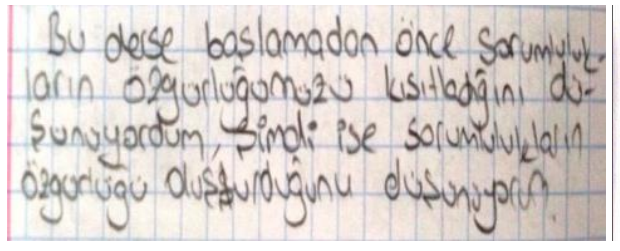

Image 6 (Nil)
Bu ders ozgürlúgú konustuk. Aslinda gorumluluklarimizin àgirlugio olusturdugu no ögrendik. Eger herkes kafasina göre davranip Sorumluluklorini gerine getirmeseydi aslinda ögürlügümüs kisitlanmis durdu.

\section{Image 7 (Zehra)}

\section{Focus Group Interview of Children Attending Philosophy Activities}

Table 7 shows the categories that emerged as a result of the analysis of the focus group interview conducted with the children in the experimental group after the philosophy education program. 
Table 7 .

Categories of Focus Group Interview Questions

\begin{tabular}{|c|c|}
\hline Focus Group Interview Questions & Categories \\
\hline $\begin{array}{l}\text { What influenced you most during the } \\
\text { philosophy activity? }\end{array}$ & $\begin{array}{l}\text { Being able to view events from different } \\
\text { angles } \\
\text { Becoming aware of different perspectives and } \\
\text { thoughts }\end{array}$ \\
\hline How did you apply what you learned here & Questioning \\
\hline in yot & Doubting \\
\hline $\begin{array}{l}\text { If you want to tell a friend what we talked } \\
\text { about here, what would you tell him about } \\
\text { this activity?? }\end{array}$ & $\begin{array}{l}\text { Understanding/recognizing } \\
\text { perspectives } \\
\text { Respecting } \\
\text { Learning to think }\end{array}$ \\
\hline $\begin{array}{l}\text { How do you think the presence/necessity of } \\
\text { such a course would affect social life? }\end{array}$ & $\begin{array}{l}\text { Empathizing } \\
\text { Being a happy community } \\
\text { Avoidance of violence } \\
\text { Making self-evaluation }\end{array}$ \\
\hline $\begin{array}{l}\text { What would you like to change about the } \\
\text { content and implementation of philosophy } \\
\text { activities? What would be your } \\
\text { suggestions?" }\end{array}$ & $\begin{array}{l}\text { Children's management of philosophy } \\
\text { activities } \\
\text { Suitable philosophy activity hours for children } \\
\text { Using different stimuli in philosophy activities } \\
\text { The contribution of philosophy activities to } \\
\text { the courses (notes, etc.) }\end{array}$ \\
\hline
\end{tabular}

The answers of the children participating in the philosophy activities to the question "what influenced you the most during philosophy activities?" during focus group interview were evaluated in categories including looking at events from different perspectives and being aware of different perspectives. "I learned that we should look for the questions and answers ourselves. Questions and answers are in us." (Ayça), "There were people with very different opinions. I said "Oh, is he/she thinking that, so there is someone thinking that way"(Nil), "I learned that human nature has questions and curiosity. I understand that there is more than one answer to a question (Saliha), I found out that I was happier when I looked at life from slightly different perspectives." (Esra), "I think we've re-learned concepts like good, ugly, good, and bad." (Ela), "I have seen how people can think differently from each other and learnt to respect opinions." (Süreya), "I realized that many things that I thought to be right are actually wrong." (Ecrin) can be given as an example.

To the question "how did you apply what you learned here in your daily life/classroom?", the children gave answers about questioning and doubting. The expressions "I' $m$ a thinking person, but I've started to think more complicated since I got here. I became very suspicious and returned to my own world." (Ela), "We question when we learn something, for example what is right for who..." (Ecrin), "I'm becoming more suspicious which is also reflected in my life." (Ayça) can be given as examples. 
For the question "What would you tell your friend about this activity if you want to tell a friend what we talked about here?", the children responded in terms of understanding different perspectives, respecting and learning to think categories. The expressions "When my friends ask about the philosophy activities, I say we think there." (Ela), "I say we look at life from different aspects." (Ayça), "I say we get everyone's opinions." (Ada), "I would say we doubted." (Nil), "I would say we've guessed" (Süreya) can be given as examples.

To the question "how the presence/necessity of such a course would affect social life?", the children approached mostly in terms of values and stated that the empathy and understanding people would increase and violence would decrease. The expressions "People have more empathy. The environment gets better when we have empathy anyway." (Ela), "Society becomes more understanding." (Süreya), "Maybe we can stop criticizing people, see our own mistakes." (Saliha), "I think anyone can think. Before doing something, the person thinks about it and behaves accordingly." (Ada), "I think one would be happy if something bad happens by thinking that it is good compared to other things." (Ayça), "I think the school will be calmer, people realize that they actually do not have to talk while thinking." (Ela), "since the society thinks more, its knowledge rate increases, they do more research." (Zehra), "I think this violence in the society, for example we get angry right away, that may decrease. Because people can be more understanding when they share instead of keeping their thoughts in their mind." (Ecrin) expressions can be given as examples.

To the question "what would you like to change about the content and application of philosophy activities? What would be your suggestions?", the children stated their opinions about the activity hours, process of philosophy discussions, the use of different stimuli and the contribution of philosophy activities to the courses. The expressions "In order to have a more discussion environment, people can discuss with respect to each other without your (the researcher) intervention by lying the chairs in a circle." (Ela), "Most people can't wake up or do not want to come when the philosophy activities are conducted at early hours. For example, our afternoon school courses can be taken as examples." (Süreya), "Men act prejudicially. They think philosophy is like literature and poetry. Next time, a subject about the equality of boys and girls can be taught." (Saliha), "For example, during discussions, one might say a problem with a friend. Everyone can discuss on a related topic." (Esra), "I think if it will contribute to the grades of the courses such as Turkish or social sciences, everyone would participate." (Nil), "Since the learning tendency of some people is visual while that of some others is auditory, short movie and cartoons can be used as stimuli." (Saliha), "For example, we present our own opinions, but we do not question the views of others. When someone else says something, we should ask, 'Why do you think so? In order to justify our thinking." (Ecrin), "In fact, even if it was compulsory, what is in the course remains in the course, it is not very effective most of time, volunteerism is better... Therefore, if philosophy activities / trainings are compulsory for the first few weeks and those who are interested in the subject come later, there will be no prejudice." (Ela) can be given as examples. 


\section{Discussion, Conclusion and Recommendations}

As a result of the study carried out using mixed model and embedded design, it was determined that the philosophy program with children had a positive effect on their attitudes towards human values. After the philosophy program, children's scores of the Human Values Scale increased significantly. In addition, the diaries filled by the children at the end of the philosophical conversations and focus group interview conducted on the day when all activities were completed, revealed positive changes in the attitudes of children towards values. It was observed that the results of the study were compatible with the studies investigating the usability of philosophy with children for moral, value and citizenship education (Akkocaoğlu Çayır \& Akkoyunlu, 2016; Burroughs \& Tuncdemir, 2017; Cam, 2014; Garrat \& Piper, 2011; McCall, 2017; Splitter, 2011). For example, in their study conducted to investigate the effect of philosophical discussions on the ethical understanding of preschool children aged between 3-5 years, Burroughs and Tuncdemir (2017) applied a 12-week education program on topics such as justice, empathy, personal welfare and participation. It was determined as a result of their studies that the participants' ability to respond ethical questions, the use of emotional markers and their justification expressions for the answers increased. In their study, Akkocaoğlu Çayır and Akkoyunlu (2016) aimed to determine how training of philosophy with children affect the third-grade elementary school children in cognitive, affective and social fields. As a result of the study, it was found that children approach to concepts socially, there was an increase in problem solving skills after philosophy education, and the philosophy program contributed to the critical thinking, citizenship and value education of the children. Cam (2014) stated in his study that teaching cooperation and questioning to children rather than teaching competition constituted the social dimension of teacher's value teaching and stressed that the philosophy course should be included in the curriculum through the academic year and this should be done through a collaborative inquiry that enables children to participate in a discreet society. He also argued that this collaborative questioning would integrate personal responsibility into social values more effectively than didactic religious education. In his study, McCall (2017) found that even fiveyear-olds gained many values such as respect for each other through philosophical inquiry, cooperation, tolerance to different ideas, and the flexibility to change their ideas and improved their related skills. Trickey and Topping (2004) reviewed 10 studies conducted in different countries about philosophy with children and stated that it is not possible to say that any use of philosophy activities with children will always lead to positive results. As a reason for this, they stated that the application integrity can be very variable and there are a wide range of evidence indicating that children can gain important skills that can be measured both academically and social through such interactive processes under certain circumstances.

In the results related to the qualitative dimension of the study, it is seen that children used the expressions in both student diaries and the focus group interviews stating that they gained the skills of looking at the events from different perspectives, comprehended the relationship of philosophy with questioning and thinking, and understood that responsibilities were a part of the freedom. Akkocaoğlu Çayır and 
Akkoyunlu (2016) found in their study that the philosophy education led children to approach events through the concepts of rights, justice and equality and raised awareness in children in listening, being patient, and respecting for different opinions. These changes in children which are compatible with the results of this study suggests that philosophy with children can be integrated with curricula in terms of having similar gains with courses such as life science and social sciences. In their study, Karadağ and Demirtaş (2018) carried out philosophy activity with preschool children and determined that both teachers and students observed positive changes after philosophy education mostly in the subjects such as thinking, reasoning their thoughts, questioning and improving in establishing communication skills. Seifi, Shahhaghi and Kalantari (2011) found as a result of their study conducted to investigate the effect of the Philosophy for Children (P4C) program on the self-esteem and problem solving skills of secondary school students that the self-confidence of the children in the experimental group increased significantly, there was a significant increase in problem focused problem solving style, and there was a significant decrease in emotion focused style. As a result of the study conducted by Tahiroğlu et al., (2013) to investigate the effect of activities they prepared by using Turkish folk tales on the attitudes of eight grade students towards human values, they determined that the activities positively affected the students' attitudes and behaviors towards the human values such as responsibility, friendship/companionship, being peaceful, respect, tolerance, and honesty. Dilmaç (2007) investigated the effect of human values education program he prepared on the attitudes of science high school students towards human values and determined as a result of his study that education program was effective in the development of the value acquisition levels of secondary school students. Eryılmaz and Çengelci Köse (2018) stated that literary products can be used in giving value education to children. In this respect, they examined the book "The Little Prince" and determined that some of the values in the book such as scientificness, aesthetic, diligence, helpfulness, respect, sensitivity, courage, patriotism, friendship, fairness, cleanliness/regularity, responsibility, honesty, love, and power were also involved in the Curriculum of Social Sciences. Lickona (1992) emphasized that value/character education is a necessity for every democratic and free society. Kohn (1997) criticized the character education programs showing limitations in value teaching and stated that it is necessary to have a philosophical perspective that deals with value teaching in a wider manner. Based on all these views and research results, it can be said that it is an appropriate way to acquire values through philosophical/thinking education with children as it provides a philosophical perspective and a more holistic approach to the situation.

Throughout the study, the children started from their own lives and presented examples from their lives in the philosophy conversations, in their diaries and focus group interviews. Kuçuradi (2015) also stated that the main purpose in philosophy education is to establish a connection between the individual's own life and what he/she has learned. Another striking element in the study is that students had difficulty in understanding satires and metaphors in texts (especially Nasrettin Hodja Jokes) which are read as a stimulus at the beginning of philosophy conversations. For this reason, after ensuring that the students understood the stimulating texts read to them 
through questions, a process from special to general was carried out. For example, after the "Key" joke, the children were asked "Why did Hodja search the key in the dark?" and then "Is it necessary to search if we want to find something?". According to the report of the educational survey "Monitoring and Assessment of Academic Skills (ABIDE)" conducted for fourth and eighth grade students throughout Turkey by the Ministry of National Education (2019), it was found that $66.1 \%$ of the students had difficulty in understanding the idioms, proverbs, irony and massages in the wits and could not establish the cause and effect relationship. Therefore, it is clear that this aspect of philosophy education should be integrated into other courses.

This study was conducted with voluntary students and all children in the sample group were girls. This might be associated with many other reasons along with the prejudice towards philosophy education in particular. However, it should be noted that it is important for boys to participate in philosophy education just like the girls because according to TSI (2017)'s data, 107.984 children including 92.849 boys and 15.135 girls have come or have been brought to the security department due to delinquency. Besides, according to the report released by UNICEF (2018), it is stated that half of the children (around 150 million students) aged between 13 and 15 years in the world are exposed to peer victimization in and around the school. When these rates are considered, it is inevitable to say that philosophy education should be introduced to every child at early ages. Charleton (2008) states that philosophical questioning and understanding contribute to a society with less social problems as well as helping young people to make reasonable choices about what they value and become more aware as consumer and more critical in their participation to the democratic process. In addition, he also emphasizes that philosophical questioning helps the young people to see that there are motivating ideas/reasons behind their certain behaviors. Similarly, McCall (2017) stated that philosophical questioning is important in the way of being effective and reasonable citizens for the benefit of both each individual child and society. The studies of Bleazby (2006) and Burgh and Yorshansky (2011) also revealed that the philosophy education with children can be used to help children to gain democratic attitude.

In conclusion, the hypothesis about the connection between training of philosophy with children and values in the introduction section was affirmed by the results of the study. The obtained data support that thinking and thus thinking education have an effective role in the formation of human values. In the study, the inability to choose sample group randomly and including only the female students constitute the methodological limitation of the study. By considering the results of the study and also the recommendations expressed by the participants in the focus group interview, the following recommendations can be made.

This study was conducted with 13 -year-old children. It can be recommended to conduct studies about the effect of philosophy on values acquisition of children during preschool and primary school in future studies.

$>$ This study was carried out with female voluntary students. Future studies including male students can be conducted. 
$>$ Considering that the development is a whole in terms of gaining values, more detailed studies that can guide parents and teachers about philosophy with children in Turkey can be conducted.

$>$ It can be recommended that philosophy with children course should be given as a compulsory course especially in secondary education within the framework of the Citizenship Education Program and in this context, trainings can be planned for families and teachers.

$>$ Philosophy clubs can be established within the schools.

> "Philosophy with Children" courses can be opened in the Public Education Centers or Schools. In order to ensure the participation and motivation of the students for courses, a system can be established in which the courses contribute to the grades of the related courses such as social sciences.

$>$ "Philosophy activities with children" can be conducted within the scope of activities in Children's Libraries. Library staff can be informed about the issue.

\section{Çıkar Çatışması ve Etik Kurallar}

Çalışma 2020 yılı öncesinde tamamlanmış olup araştırmanın tüm süreçlerinde etik kurallara uyulmuştur. Ayrıca, yazarlar arasında herhangi bir çıkar çatışması bulunmamaktadır.

\section{References}

Akkocaoğlu Çayır, N., \& Akkoyunlu, B. (2016). Çocuklar için felsefe eğitimi üzerine nitel bir araştırma. Turkish Online Journal of Qualitative Inquiry (TOJQI), 7(2), 97-33.

Bleazby, J. (2006). Autonomy, democratic community, and citizenship in philosophy for children: Dewey and philosophy for children's rejection of the individual/ community dualism. Analytic Teaching, 26(1), 30-52.

Boyatzis, R. E., Murphy, A. J., \& Wheeler, J. W. (2000). Philosophy as a missing link between values and behavior. Psychological Reports, 86(1), 47-64.

Burgh, G., \& Yorshansky, M. (2011). Communities of inquiry: Politics, power and group dynamics. Educational Philosophy and Theory, 43(5), 436-452.

Burroughs, M. D., \& Tuncdemir, T. B. A. (2017). Philosophical ethics in early childhood: A pilot study. Journal of Philosophy in Schools, 4(1), 74-101.

Büyüköztürk, Ș. (2011). Deneysel desenler: Öntest sontest kontrol gruplu desen ve veri analizi. Ankara: Pegem Akademi Yayıncılık.

Büyüköztürk, Ş., Kılıç Çakmak, E., Akgün, Ö. E., Karadeniz, Ş., \& Demirel, F. (2018). Bilimsel araştırma yöntemleri. Ankara: Pegem Akademi Yayıncılık.

Bynum, T. W. (1976). What is philosophy for children? An introduction. Metaphilosophy, 7(1), $1-6$.

Cam, P. (2014). Philosophy for children, values education and the inquiring society. Educational Philosophy and Theory, 46(11), 1203-1211.

Charleton, M. (2008). Educating for values: Philosophy and religion, Studies: An Irish Quarterly Review, 97(386), 193-203. 
Creswell, J, W., \& Plano Clark, V. L. (2015). Karma yöntem araştırmaları: Tasarımı ve yürütülmesi. (Yüksel Dede ve Selçuk Beşir Demir, Çev. Ed.), Ankara: Anı Yayıncılık.

Çotuksöken, B. (2015). Düşünme eğitiminin güncel durumu ve sorunları. B. Çotuksöken ve H. Tepe (Yay. Haz.). Çocuklar için felsefe eğitimi (s. 33-48) içinde. Ankara: Türkiye Felsefe Kurumu.

Dilmaç, B. (2007). Bir grup fen lisesi öğrencisine verilen insani değerler eğitiminin insani değerler ölçeği ile sınanması (Yayımlanmamış doktora tezi). Selçuk Üniversitesi, Konya.

Droit, R. P. (2017). Çocuklarla felsefe sohbetleri. İstanbul: Say Yayınları.

Eryılmaz, Ö., \& Çengelci Köse, T. (2018). Sosyal bilgilerde edebi ürünler ve değerler eğitimi: Küçük Prens örneği, Batı Anadolu Eğitim Bilimleri Dergisi, 9(1), 65-79.

Garrat, D., \& Piper, H. (2011). Citizenship education and philosophical enquiry: putting thinking back into practice. Education, Citizenship and Social Justice, 7(1), 71-84.

Haas H. J. (1976). The value of "Philosopy for children" within the Piagetian framework, Metaphilosophy, 7(1), 70-75.

Horner C., \& Westacott E. (2011). Felsefe aracılığıyla düşünme. Ankara: Phoenix Yayınevi.

Karadağ, F., \& Demirtaş, V. Y. (2018). Çocuklarla felsefe öğretim programı'nın okul öncesi dönemdeki çocukların eleştirel düşünme becerileri üzerindeki etkililiği. Eğitim ve Bilim, 43(195), 19-40.

Kinnier R. T., Kernes J. L., \& Dautheribes T.M. (2000). A short list of universal moral values. Counseling and Values, 45, 4-16.

Kitchener, R. F. (1990). Do children think philosophically? Metaphilosophy, 21(4), 416-431.

Kohn, A. (1997). How not to teach values: A critical look at character education. Phi Delta Kappan, 78, 428-439.

Kuçuradi, İ. (2015). Türkiye'de felsefe eğitimi. Çocuklar için felsefe eğitimi (s. 113-118) içinde (Yay Haz. B. Çotuksöken ve H. Tepe). Ankara: Türkiye Felsefe Kurumu.

Kulaksızoğlu A. (2014). Kişisel gelişim uygulamaları, İstanbul: Nobel Yayıncılık.

Lickona, T. (1992). Educating for character: How our schools can teach respect and responsibility. Bantam. [Çevrim-içi: http://www.penguinrandomhouse.com/books/101383/educating-for-character-by-thomaslickona/9780553370522/] Erişim tarihi: 10.07.2019.

Lipman M. (1976). Philosopy for children. Metaphilosophy, 7(1), 17-39.

Lipman, M. (1988). Philosophy goes to school, Philadephia: Temple University Press.

Lone J. M. (2017). Filozof çocuk, İstanbul: Sola Yayınları.

Matthews, G. B. (2000). Çocukluk felsefesi. İstanbul: Gendaş Kültür.

McCall C.C. (2017). Düşünmeyi dönüştürmek: İlk ve orta sınıflarda felsefi sorgulama, İstanbul: Nobel Yayıncilik.

Merriam, S. B. (2015). Nitel arşatırma. (Selahattin Turan, Çev. Ed.). Ankara: Nobel Yayıncılık. 
Miles, M. B., \& Huberman, A. M. (2015). Nitel veri analizi. (Sadegül Akbaba Altun \& Ali Ersoy, Çev. Ed.). Ankara: Pegem Yayıncılık.

Ministry of National Education (2010). 18. Milli Eğitim Şurası Çalıştay Raporu Değerler Eğitimi Yönergesi. Erişim adresi: http://mebk12.meb.gov.tr/meb_iys_dosyalar/34/39/749197/dosyalar/2015_02/09093609_ degerleregitimi.pdf]

Ministry of National Education (2019). Akademik Becerilerin İzlenmesi ve Değerlendirilmesi (ABIDE). Erişim adresi: abide.meb.gov.tr

Moshman, D. (1998). Cognitive development beyond childhood: Constraints on cognitive development and learning. In W. Damon (Series Ed.), D. Kuhn, \& R. Siegler (Vol. Eds.), Handbook of child psychology: Vol. 2. Cognition, language, and perception (5th ed., pp. 947-978). New York: Wiley.

Piaget, P. (1933). Children's Philosophies. Carl Murchison, Worcester, (Ed.). In a handbook of child psychology, (p. 534-547.). MA: Clark University Press.

Portelli J. J. (1990). The Sokratik Method and philosophy for children. Metaphilosophy, 21, 141-161.

Pritchard, M. (2002). Philosophy for children. Erişim adresi: https://plato.stanford.edu/entries/children/]

Seifi, G. M., Shaghaghi, F., \& Kalantari, M. S. (2011). Efficacy of philosophy for children program (P4C) on self-esteem and problem solving abilities of girls. Journal of Applied Psychology, 5(2), 66-83.

Seligman, M. E. P. (2007). Gerçek mutluluk. Ankara: HYB Basın Yayım.

Splitter, L. (2011). İdentity, citizenship and moral education. Educational Philosophy and Theory, 43(5), 484-505.

Tahiroğlu, M., Kayabaşı, O. A., \& Kayabaşı, R. G. (2013). The effect of Turkish Folk Tales on students' attitudes towards human values. Journal of Theoretical Educational Science, 6(4), 477-495.

Trickey, S., \& Topping, K. J. (2004). Philosophy for children: a systematic review. Research Papers in Education, 19(3), 365-380.

UNESCO (2007). Philosophy A School Of Freedom. Teaching Philosophy and Learning to Philosophize: Teaching Philosophy And Learning To Philosophize: Status and Prospectus.Paris.

UNICEF (2018). End violence against children in schools. Erişim adresi: http://unicef.org.tr

UNESCO (2005). Learning to do: Values for learning and working together in a globalized world. An Integrated Approach to Incorporating Values Education in Technical and Vocational Education and Training. Bonn, Germany: UNESCO-UNEVOC. Erişim adresi: http://www.unevoc.unesco.org

Wartenberg T. E. (2018). Küçük çocuklar için büyük fikirler. Ankara: Sentez Yayıncılık.

Worley, P. (2019). Felsefe makinesi. İstanbul: Paraşüt Kitap. 
Yıldırım, A., \& Şimşek, H. (2013). Sosyal bilimlerde nitel araştirma yöntemleri. Ankara: Seçkin Yayıncılık.

Zeldin T. (2014). İnsanlığın mahrem tarihi. İstanbul: Ayrıntı Yayınları.

\section{References Used in Philosophy Program}

Alkan, T. (2003). Ezop masallar. İstanbul: Bordo Siyah Klasik Yayınlar.

Brenifier, O., \& Millon, I. (2016). Nasrettin Hoca ile düşünmeyi öğrenmek. İzmir: Tudem.

Direk, N. (2012). Çocuklarla felsefe. İstanbul: Pan Yayıncılık.

Droit, R. P. (2017). Çocuklarla felsefe sohbetleri. İstanbul: Say Yayınları.

Fuat, M. (2015). Çocuklar için Nasrettin Hoca fikraları. İstanbul: Türkiye İş Bankası Kültür Yayınları.

Labbe, B. \& Beurier, P. (2016). Çıtır çıtır felsefe. İstanbul: Günışığı Kitaplığı.

Liberman, J. M. (2015). Masal terapi. İstanbul: Doğan Novus.

\section{Genişletilmiş Özet}

Çocuklarla felsefe yapmanın mümkün olduğunu ilk dile getiren Mathew Lipman olmuştur. Lipman, çocukların küçük yaşlardan itibaren soyut düşünebildiklerini ve felsefi soruları anlayabildiklerini savunmaktadır. Onun amacı belirli bir felsefi görüşü öğretmek yerine hak, adalet, şiddet gibi evrensel kavramlardan hareketle çocuğun kendi akıl yürütme yetisini harekete geçirmeye ve soru sormasını sağlamaya çalışmaktır. İlgili literatürdeki yaygın kanıya göre, çocuklarla felsefe programı, çocuklarının ihtiyaç duyduğu eleştirel düşünme, akıl yürütme, okuma, matematik, konsantrasyon, işbirliği yapma, benlik saygısı, özgüven, zorbalığı azaltma, iletişim ve kişiler arası ilişkiler gibi birçok alanda önemli kazançlar sağlamaktadır. Bireylerin kendi yaşamlarında ve toplumda yer alan değerleri yansıtabilmeleri için ahlak felsefesi eğitimi gereklidir. Dünyanın en yaşanılabilir yerlerinde bile güvenlik sorunları yüz göstermişken, insani değerler konusu da oldukça tartışılır olmuştur. Bireylerin kendi yaşamlarında ve toplumda yer alan değerleri yansıtabilmeleri için ahlak felsefesi eğitimi gereklidir. İnsani değerlerin neler olduğu konusunda çeşitli görüşler mevcuttur. Örneğin, Seligman'a göre değerler, erdemli davranışlar olarak ele alınmıştır. Seligman, karakter güçleri olarak erdemli davranışları; bilgelik bilgi, insanlık sevgi, adalet, ılımlılık, cesaret ve aşkınlık olarak gruplamıştır. Kinnier, Kernes ve Dautheribes evrensel ahlaki değerler için dört ana kategori oluşturmuştur; kendinden daha büyük bir şeye bağlılık, tevazu ile birlikte öz-sayg1, öz-disiplin, kişisel sorumlukları kabul etme, başkalarına saygı ve özen gösterme, başka canlılar ve çevreye özen gösterme. Kulaksızoğlu ise ahlaki (insani) değerleri; sevme, doğru davranma, iyilik yapma, barışçı olma, çalışma, bilgi edinme şeklinde sınıflandırmıştır.

$\mathrm{Bu}$ araştırmanın amacı; çocuklarla felsefe eğitiminin yedinci sınıfa devam eden çocukların insani değerlere yönelik tutumları üzerindeki etkisini incelemektir. 
Buradan hareketle; "Çocuklarla felsefenin çocukların insani değerlere yönelik tutumları üzerinde etkisi var mıdır?" ve "Çocuklarla felsefenin çocukların insani değerlere yönelik tutumları üzerindeki etkisi nasıldır?” sorularına yanıt aranmıştır. Araştırmacılar tarafindan 10 haftalık felsefe programı oluşturulmuştur. Programda belirlenen konular Milli Eğitim Bakanlığı Değerler Eğitimi Yönergesinde belirtilen değerlere uygun olarak oluşturulmuştur. Etkinlik kapsamında ele alınacak konular sırasıyla; Felsefe nedir?, Kanaat/İnanmak ve Bilmek, İyi ve Kötü, Gerçekten ve Yalancıktan, Ahlaki Olan ve Olmayan, Mutluluk ve Mutsuzluk, Güzellik ve Çirkinlik, Doğa ve Kirlilik, Savaş ve Barış/Şiddet ve Şiddetsizlik, Özgür Olan ve Olmayan/Adalet ve Haksızlık/Haklar ve Ödevler konularıdır. Her hafta her konu için kullanılabilecek uyarıcı metinler belirlenmiş, uyarıcı metinlerden yola çıkarak tartışmayı yönlendirici sorular oluşturulmuş ve her oturum sonrasında hedeflenen kazanımlar belirlenmiştir. Her oturum süresi konuya göre değişkenlik göstermekle birlikte ortalama 60 dakika sürmüştür. Araştırmaya Kırklareli Merkezde bir ortaokula devam eden 13 yaş grubu 10 deney 10 kontrol olmak üzere toplam 20 öğrenci katılmıştır. Öğrenciler amaçlı örnekleme yöntemine göre belirlenmiştir. Buna göre, yedinci sınıfa devam eden, cumartesi günleri etkinliklere katılabilecek ve gönüllülük gösteren 10 öğrenci deney grubu için seçilmiştir. Araştırmada karma model ve iç içe desen kullanılmıştır. Araştırmanın nicel boyutunda öntest, sontest kontrol gruplu deneysel desen kullanılmıştır. Araştırmanın nicel boyutunda çocukların insani değerlere yönelik tutumlarını belirlemek amacıyla İnsani Değerler Ölçeği (IDÖ) kullanılmıştır. Araştırmanın nitel boyutunda durum deseni kullanılmışıır. Verilerin toplanmasında doküman incelemesi ve odak grup görüşmesinden yararlanılmıştır. Felsefe etkinliklerinin ilk haftasından itibaren her oturum sonunda öğrenci günlükleri oluşturulmuştur. 'Araştırmacının ürettiği dokümanlar' olarak değerlendirilen öğrenci günlükleri bu araştırmada olay/kişi/durum hakkında daha fazla bilgi elde etmek için oluşturulmuştur. Öğrenciler gerçekleștirilen her oturum sonrasında o günkü deneyim ve düşüncelerine ilişkin görüşlerini yazmışlardır. Felsefe etkinliklerinin son haftasında ise felsefe etkinliklerine katılmış olan tüm öğrencilerle odak grup görüşmesi yapılmıştır. Nicel verilerin analizinde SPSS paket programı kullanılmış olup, Mann Whitney U testi ve Wilcoxon testi uygulanmıştır. Nitel veriler analiz edilirken odak grup görüşmesi için içerik analizi, doküman incelemesi için betimsel analiz kullanılmıştır. Bunun için odak grup görüşmesine ait veriler araştırmacı tarafindan dikte edilmiş verilere yönelik kategoriler oluşturulmuştur.

Elde edilen veriler, çocuklarla felsefe programının insani değerlerin oluşumunda etkili bir rol oynadığını desteklemektedir. Araştırmada örneklem grubunun rastgele seçilememesi ve araştırmaya sadece kız öğrencilerin dahil edilmesi çalışmanın metodolojik sınırlamasını oluşturmaktadır. Araştırmanın sonucunda İnsani değerler ölçeğine ait öntest puanlarının farklılık göstermediği, sontest öntest puan farklarının deney grubu lehine olacak biçimde farklılık gösterdiği, deney grubunda yer alan çocukların sontest öntest puanlarının sontest puanları lehinde farklılaştığı ve kontrol grubunda yer alan çocukların sontest öntest puanlarının farklılaşmadığı göz önüne alındığında, felsefe programının çocukların insani değerlere yönelik tutumları 
üzerinde olumlu bir etkiye neden olduğu bulunmuştur (zdeney $(10)=-2,81, p=0,01$, $\mathrm{p}<0,05)$. Deney grubundaki çocuklar günlüklerinde ve felsefe eğitimi sonrasında gerçekleştirilen odak grup görüşmesinde felsefe eğitiminin hem kendi yaşantılarına hem eğitim yaşantılarına hem de toplumsal açıdan yarattığı/yaratacağı farka yönelik olumlu görüşler belirtmişlerdir. 